\title{
HUBUNGAN POLA MAKAN DENGAN TIMBULNYA GASTRITIS PADA PASIEN DI UNIVERSITAS MUHAMMADIYAH MALANG MEDICAL CENTER (UMC)
}

\section{Correlation Between Diet With Gastritic Incidence On Patient In Medical Center Of Muhammadiyah Malang}

\author{
Rona Sari Mahaji Putri', Hanum Agustin², Wulansari ${ }^{3}$ \\ ${ }^{1,2,3)}$ Program Studi Ilmu Keperawatan Fakultas Ilmu kesehatan \\ Universitas Tribhuwana Tunggadewi Malang \\ Jl. Telaga Warna, Tlogomas, Malang 65144 \\ *)e-mail: putrirona@gmail.com
}

\begin{abstract}
ABSTRAK
Gastritis merupakan masalah kesehatan di masyarakat. Di Indonesia prevalensi gastritis sebanyak 0,99\% dan insiden gastritis sebesar 115/100.000 penduduk. Ketidakseimbangan faktor agresif dan defensif lambung dapat menyebabkan gastritis. Faktor ini dipengaruhi antara lain oleh pola makan, kebiasaan merokok, konsumsi NSAID dan kopi. Penelitian ini bertujuan untuk mengetahui hubungan pola makan dengan timbulnya gastritis pada pasien di Universitas Muahammdiyah Malang Medical Center (UMC). Metode penelitian analitik observasional dengan pendekatan case control. Subyek penelitian adalah semua pasien gastritis di UMC, dengan menggunakan tehnik total sampling. Instrumen menggunakan recall 2 x 24 jam dan kuesioner. Analisis data menggunakan uji spearman rank correlation dengan program komputer. Hasil analisis didapatkan $p$ value $=0,009$ yang berarti ada hubungan antara pola makan dengan timbulnya gastritis pasien di UMC. Direkomendasikan pada pasien gastritis dan masyarakat agar mengkonsumsi makanan yang bergizi dengan jumlah makanan yang cukup, jenis makanan yang bervariasi serta frekuensi makan yang sedikit tapi sering sesuai dengan kebutuhan tubuh.
\end{abstract}

Kata kunci: pola makan, gastritis

\begin{abstract}
Gastritis is a kind of health problem in society. In Indonesia, the prevalence of gastritis is about 0,99\% and the incidence of gastritis is about 115/100.000 people. The unbalance of aggressive factors and ulcer defensive can cause gastritis. This factor is influenced by the eating habit, smoking habit, consuming NSAID and coffee. This study aims to identify the relationship of eating habit with the arising of gastritis. In this research, the population is all of the gastritis patients; the sampling technique used is sampling total which take all of the gastritis patients as samples, whereas it uses recall $2 \times 24$ hours and questionnaire as the instrument of the research. Then the result of the questionnaire is analyzed by computer program for windows with spearman rank test. The result of spearman rank test, it is founded that value $=0,009$ so which states there is a relationship of eating habit with the arising of gastritis. Because of the existence of the relationship between eating habit and the arising of gastritis, it is recommended for the gastritis patient and society to consume healthy food with proportional amount, eat various foods and have a few portions but often of eating accord with bodily needs.
\end{abstract}

Keywords: eating habit, gastritis

\section{LATAR BELAKANG}

Gastritis adalah peradangan lokal atau menyebar pada mukosa lambung, yang berkembang bila mekanisme protektif mukosa dipenuhi dengan bakteri atau bahan iritan lain (Rafani, 2009) .

Gastritis merupakan masalah kesehatan di masyarakat. Di Indonesia prevalensi gastritis sebanyak $0,99 \%$ dan 
insiden gastritis sebesar 115/100.000 penduduk. Ketidakseimbangan faktor agresif dan defensif lambung dapat menyebabkan gastritis. Faktor ini dipengaruhi antara lain oleh pola makan, kebiasaan merokok, konsumsi NSAID dan kopi (Rafani, 2009). Dari hasil penelitian para pakar, didapatkan jumlah penderita Gastritis antara pria dan wanita, ternyata gastritis lebih banyak pada wanita dan dapat menyerang sejak usia dewasa muda hingga lanjut usia. Di Inggris 6-20\% menderita gastritis

pada usia 55 tahun dengan prevalensi $22 \%$ insiden total untuk segala umur pada tahun 1988 adalah 16 kasus/1000 pada kelompok umur 45-64 tahun. Insiden sepanjang usia untuk Gastritis adalah 10\% (Riyanto, 2008). Berdasarkan data yang diperoleh dari studi pendahuluan ditemukan 431 orang pasien pada tahun 2009 sehingga dapat diambil ratarata 36 pasien per bulan dengan gastritis yang datang berobat ke UMM Medical Center, jumlah pasien terbanyak ada di Bulan Oktober-Desember 2009 yaitu 61 pasien dalam Bulan Oktober, sebanyak 46 pasien di Bulan November, dan 47 pasien di Bulan Desember totalnya 154 pasien. Dari total 154 pasien, sebanyak 21 pasien datang dengan keluhan mual, sehari belum makan, sebanyak 34 pasien dengan keluhan mual, telat makan, muntah disertai nyeri perut. 15 orang dengan keluhan nyeri perut dan perut kembung, tadi pagi habis makan masakan pedes, sebanyak 11 orang dengan keluhan mual, tadi pagi habis minum kopi. Sedangkan 73 pasien lainnya datang dengan keluhan mual muntah nyeri perut saja. Berarti masih cukup banyak jumlah penderita gastritis dengan pola makan yang kurang benar saat ini. Sehingga peneliti tertarik untuk mengetahui hubungan pola makan dengan timbulnya gastritis.

Gastritis (inflamasi mukosa lambung) sering akibat diet yang salah. Kadang, gastritis dapat menyebabkan pendarahan pada lambung, tapi hal ini jarang menjadi parah kecuali bila pada saat yang sama juga terjadi luka kronis pada lambung. Pendarahan pada lambung dapat menyebabkan muntah darah atau terdapat darah pada feces dan memerlukan perawatan segera (Rafani, 2009). Pola makan yang tidak teratur, lambung menjadi sensitif bila asam lambung meningkat. Produksi $\mathrm{HCl}$ (asam lambung) yang berlebihan dapat menyebabkan terjadinya gesekan pada dinding lambung dan usus halus, sehingga timbul rasa nyeri yang disebut tukak lambung. Gesekan akan lebih parah kalau lambung dalam keadaan kosong akibat makan tidak teratur yang pada akhirnya akan mengakibatkan perdarahan pada lambung (Rafani, 2009).

\section{METODE}

Jenis penelitian adalah penelitian analitik observasional dengan desain case control. Menggunakan tehnik total sampling dengan jumlah sample adalah pasien gastritis sebanyak 36 responden yang memenuhi kriteria (tidak menderita penyakit kronis lain dan bersedia menjadi responden). Penelitian dilaksanakan pada bulan Februari sampai dengan Maret 2009 di UMM medical centre Malang.

Instrumen yang digunakan dalam penelitian adalah kuesioner mengenai pola makan yang meliputi jumlah, jenis, dan frekuensi makan yang diperoleh dengan cara recall 2 x 24 jam (menanyakan secara langsung yang dikonsumsi oleh responden dengan cara bertanya mundur ke belakang selama 2 x 24 jam). Kemudian hasil diolah dan dimasukkan ke dalam kategori skor, dengan rincian sebagai berikut: kategori pola makan sangat baik $(81,25-100 \%)$, baik $(62,5-$ $81,24 \%)$, cukup baik $(43,75-62,4 \%)$, dan kurang baik (25-43,74\%). Sedangkan timbulnya gastritis diperoleh dengan menggunakan kuesioner, yang kemudian hasilnya dimasukkan skor, dengan rincian sebagai berikut: gastritis akut (1-7), dan gastritis kronis (8-14). Penelitian menggunakan uji analisa statistik spearman rank correlation dengan menggunakan program komputer for windows dengan alpha 0,05 dengan uji. 


\section{HASIL DAN PEMBAHASAN}

\section{Hasil}

\section{Data Umum}

\section{Karakteristik Responden Berdasarkan Umur}

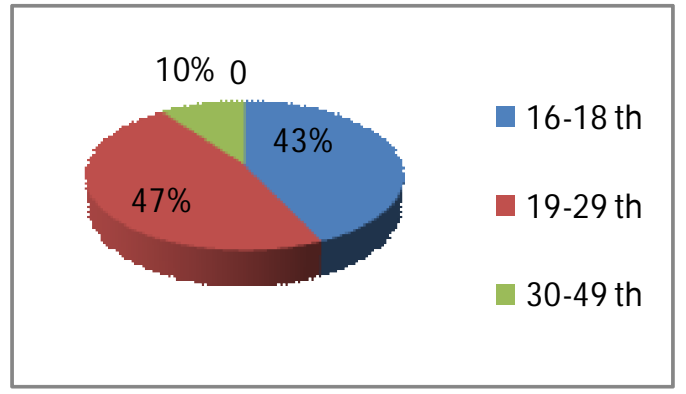

Gambar 1. Diagram distribusi frekuensi responden menurut umur

Dari gambar 1 didapatkan hasil penelitian bahwa sebanyak 13 responden (43\%) berusia antara 16-18 tahun, 14 responden $(47 \%)$ berusia antara 19-29 tahun, dan tiga responden $(10 \%)$ berusia antara $30-$ 49 tahun.

\section{Karakteristik Responden Berdasarkan Jenis Kelamin}

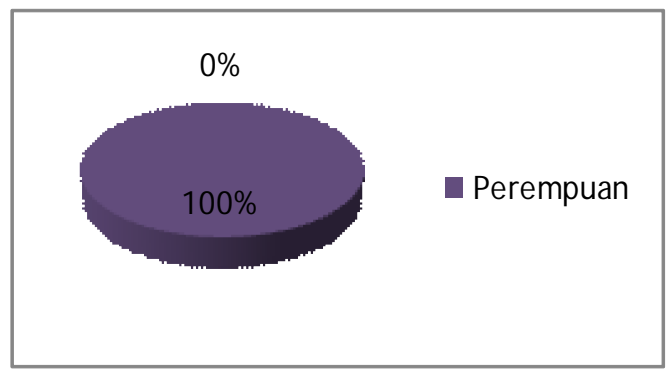

Gambar 2. Diagram distribusi frekuensi responden berdasarkan jenis kelamin

Dari gambar 2 didapatkan hasil penelitian bahwa seluruh responden (100\%) berjenis kelamin perempuan.

\section{Karakteristik Responden Berdasar Berat Badan}

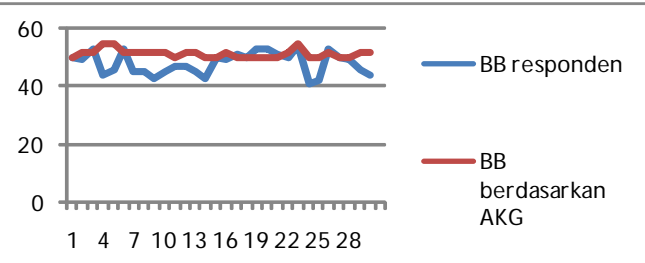

Gambar 3. Grafik perbandingan BB aktual responden dengan $\mathrm{BB}$ berdasarkan AKG

Dari grafik 1 dapat diketahui perbandingan berat badan aktual responden dengan berat badan berdasarkan angka kecukupan gizi (AKG), yaitu sebanyak 19 responden $(63 \%)$ memiliki berat badan kurang dari berat badan berdasarkan AKG, 6 responden (20\%) memiliki berat badan lebih dari AKG, dan 5 responden (17\%) memiliki berat badan sama dengan berat badan berdasarkan AKG.

\section{Data Khusus}

\section{Pola Makan}

- Jumlah makanan : Dari hasil penelitian dapat diketahui bahwa semua responden $(100 \%)$ mengonsumsi makanan yang kurang dari kebutuhan tubuh.

- Jenis makanan: Dari hasil penelitian dapat diketahui bahwa semua responden $(100 \%)$ mengonsumsi jenis makanan yang tidak bervariasi.

- $\quad$ Frekuensi makan

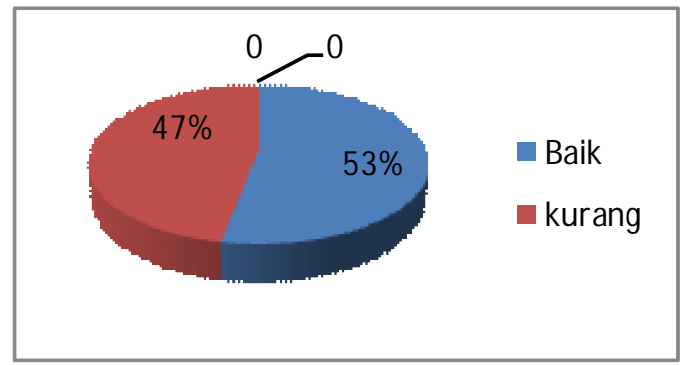

Gambar 4. Diagram distribusi frekuensi responden berdasar frekuensi makan 
Dari hasil penelitian dapat diketahui sebanyak 16 responden (53\%) memiliki frekurensi makan baik dan 14 responden (47\%) memiliki frekuensi makan kurang.

\section{Konsumsi Makan Berdasarkan Unsur Zat Gizi}

- $\quad$ Nilai karbohidrat berdasarkan AKG

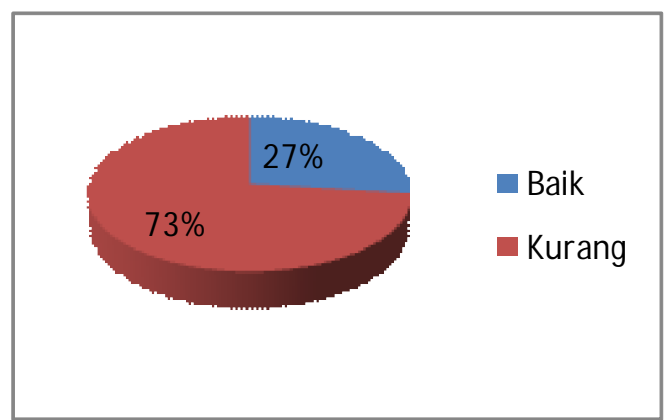

Gambar 5. Diagram distribusi frekuensi responden berdasarkan nilai karbohidrat

Dari hasil penelitian dapat diketahui sebanyak 8 responden (27\%) mempunyai nilai gizi karbohidrat baik, dan 23 responden (73\%) mempunyai nilai gizi kabohidrat kurang.

- $\quad$ Nilai protein berdasarkan AKG

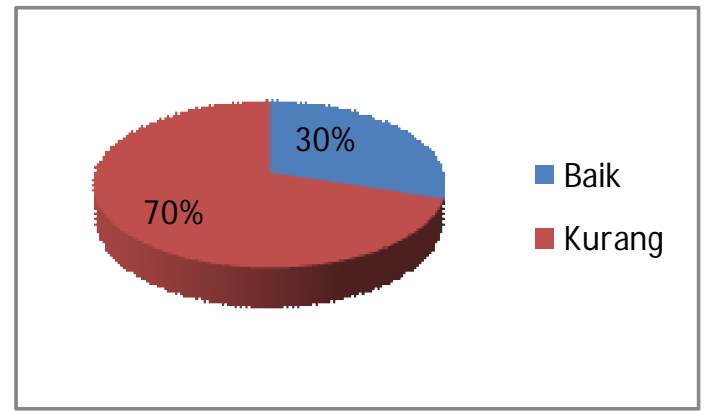

Gambar 6. Diagram distribusi frekuensi responden berdasarkan nilai protein

Dari hasil penelitian dapat diketahui bahwa sebanyak 9 responden $(30 \%)$ mempunyai nilai gizi protein baik, sedangkan
21 reponden $(70 \%)$ mempunyai nilai gizi protein kurang.

- Nilai lemak berdasarkan AKG

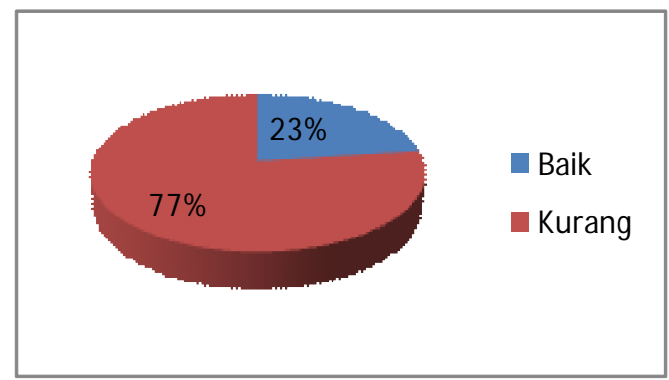

Gambar 7. Diagram distribusi frekuensi responden berdasarkan nilai lemak

Dari hasil penelitian dapat diketahui sebanyak 7 responden (23\%) mempunyai nilai gizi lemak baik, sedangkan 23 responden (77\%) mempunyai nilai gizi lemak kurang.

\section{Pola Makan Pasien Gastritis di UMM Medical Center Malang}

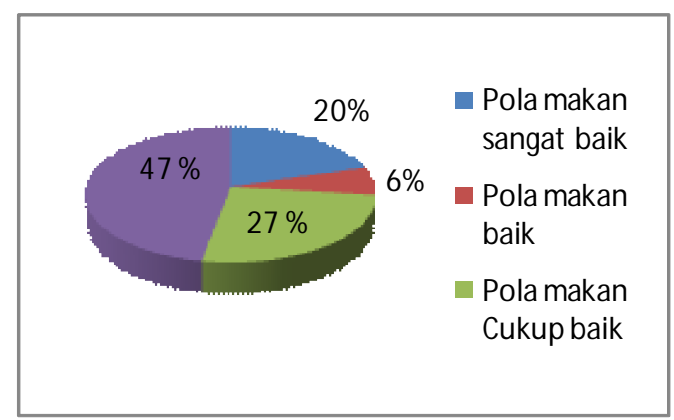

Gambar 8. Diagram distribusi frekuensi responden berdasarkan pola makan pasien gastritis di UMM Medical Center Malang

Dari hasil penelitian dapat diketahui sebanyak 6 responden (20\%) dalam kategori pola makan sangat baik, sebanyak 2 responden $(6 \%)$ dalam kategori pola makan baik, sebanyak 8 responden $(27 \%)$ dalam kategori pola makan cukup baik, dan 14 responden (47\%) dalam kategori pola makan kurang baik. 


\section{Gastritis Di UMM Medical Center Malang}

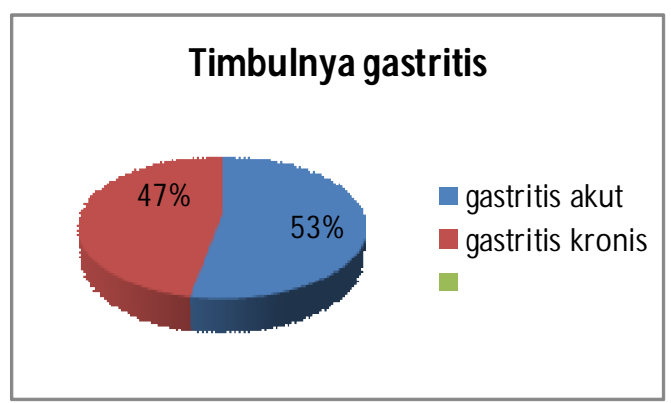

Gambar 9. Diagram distribusi frekuensi responden berdasarkan timbulnya gastritis di UMM Medical Center Malang
Dari hasil penelitian dapat diketahui sebanyak 16 responden (54\%) dalam kelompok gastritis akut, dan 14 responden $(47 \%)$ dalam kelompok gastritis kronis.

\section{Hubungan Pola Makan Dengan Timbulnya Gastritis di UMM Medical Center Malang}

Tabel 1. Hubungan pola makan dengan timbulnya gastritis di UMM Medical Center Malang

\begin{tabular}{cccccccc}
\hline No & $\begin{array}{c}\text { Skor pola } \\
\text { makan }\end{array}$ & \multicolumn{2}{l}{ Gastritis akut } & \multicolumn{2}{c}{ Gastritis kronis } & \multicolumn{2}{c}{ Total } \\
\hline $\mathbf{1}$ & Sangat & $\mathbf{n}$ & $\mathbf{\%}$ & $\mathbf{n}$ & $\mathbf{\%}$ & $\mathbf{n}$ & $\mathbf{\%}$ \\
& baik & & $(16,7 \%)$ & 1 & $(3,3 \%)$ & 6 & $(20 \%)$ \\
$\mathbf{2}$ & Baik & 2 & $(6,7 \%)$ & 0 & - & 2 & $(6,7 \%)$ \\
$\mathbf{3}$ & $\begin{array}{c}\text { Cukup } \\
\text { baik }\end{array}$ & 4 & $(13,3 \%)$ & 4 & $(13,3 \%)$ & 8 & $(26,7 \%)$ \\
$\mathbf{4}$ & $\begin{array}{c}\text { Kurang } \\
\text { baik }\end{array}$ & 5 & $(16,7 \%)$ & 9 & $30 \%$ & 14 & $(46,7 \%)$ \\
& Total & 16 & $(53,3 \%)$ & 14 & $(46,7 \%)$ & 30 & $(100 \%)$ \\
\hline
\end{tabular}

Dari tabel 1 didapatkan hasil penelitian bahwa pada kategori pola makan sangat baik yang menderita gastritis akut sebanyak 5 responden $(16,7 \%)$ dan satu responden $(3,3 \%)$ menderita gastritis kronis, pada kategori pola makan baik terdapat 2 responden $(6,7 \%)$ yang menderita gastritis akut dan tidak ada yang menderita gastritis kronis, pada kategori pola makan cukup baik terdapat 4 responden $(13,3 \%)$ yang menderita gastritis akut dan 4 responden $(13,3 \%)$ menderita gastritis kronis, sedangkan untuk kategori pola makan kurang baik terdapat 5 responden $(16,7 \%)$ menderita gastritis akut dan 9 responden (30\%) menderita gastritis kronis.

Dari hasil analisis statistik menggunakan spearman rank correlation dengan menggunakan bantuan program komputer for windows, didapatkan nilai $p$ value $=0,009$ dan kekuatan hubungan sebesar $r=0,472$.

\section{Pembahasan}

Dari diagram distribusi frekuensi responden menurut umur menunjukkan sebanyak 14 responden (47\%) penderita berusia 19-29 tahun. Ini berarti gastritis lebih banyak diderita pada usia dewasa muda. Sependapat dengan teori bahwa gastritis menyerang sejak usia dewasa muda hingga lanjut usia (Riyanto, 2008). Pada usia tersebut semua responden yang masih berstatus mahasiswa sering tidak terkontrol dalam asupan makannya, disebabkan antara lain oleh karena kesibukan, dan sudah adanya ketertarikan terhadap lawan jenis sehingga pada usia tersebut berusaha semaksimal mungkin untuk melangsingkan tubuh dengan mengurangi makan. Yang perlu dipahami bahwa pada usia ini sebenarnya sangat diperlukan adanya pemenuhan semua zat gizi 
karena tumbuh kembang yang belum mencapai maksimal.

Dari diagram distribusi frekuensi responden menurut jenis kelamin menunjukkan semua responden adalah perempuan. Gastritis lebih banyak diderita perempuan, karena kaum perempuan lebih peduli dan perhatian pada berat badan dan penampilan, sehingga perempuan berusaha menurunkan berat badan melalui jalan mengatur frekuensi, jumlah dan jenis makanan konsumsi sebisa mungkin agar tidak menjadi gemuk. Hal ini sependapat dengan teori yang menyatakan bahwa jumlah penderita gastritis lebih banyak perempuan dibanding pria (Riyanto, 2008).

Dari grafik perbandingan berat badan aktual responden dengan berat badan berdasarkan AKG menunjukkan sebanyak 19 responden $(63 \%)$ memiliki berat badan kurang, sebanyak 6 responden (20\%) memiliki berat badan lebih dan 5 responden $(17 \%)$ memiliki berat badan sama dengan berat badan berdasarkan AKG. Berat badan yang kurang disebabkan karena asupan jumlah makanan yang kurang dari kebutuhan tubuh dan jenis makanan yang kurang bervariasi.

Dari hasil distribusi frekuensi jumlah makanan, dari seluruh responden sebanyak $100 \%$ mengonsumsi jumlah makanan yang kurang dari kebutuhan tubuh. Jumlah asupan makanan yang kurang menyebabkan tidak terpenuhinya kebutuhan dan kecukupan kalori tubuh. Hal ini mengakibatkan kurang terpenuhinya energi dan unsur-unsur gizi lain yang dibutuhkan oleh tubuh.

Berdasarkan jenis makanan, seluruh responden mengkonsumsi jenis makanan yang tidak bervariasi. Namun demikian telah memenuhi komposisi makanan yang baik.

Dari diagram distribusi frekuensi responden berdasar frekuensi makan menunjukkan bahwa sebanyak 16 responden (53\%) memiliki frekuensi makan baik dan 14 responden (47\%) memiliki frekuensi makan kurang. Frekuensi atau jumlah makan dalam sehari yang baik disebabkan karena kesadaran yang tinggi oleh para responden akan pentingnya makan dengan frekuensi yang teratur. Sedangkan frekuensi makan yang kurang pada responden dipengaruhi karena faktor kebiasaan makan, diet serta menjaga berat badan tetap ideal agar penampilan tetap terjaga. Frekuensi makan yang tidak teratur membuat lambung sulit beradaptasi, sehingga asam lambung menjadi meningkat. Asam lambung yang meningkat akan mengiritasi dinding mukosa lambung sehingga timbul gastritis.

Dari diagram distribusi frekuensi responden berdasarkan nilai karbohidrat menunjukkan bahwa sebanyak 8 responden (27\%) mempunyai nilai gizi karbohidrat baik, dan 23 responden (73\%) mempunyai nilai gizi kabohidrat kurang. Nilai gizi kabohidrat yang kurang dapat disebabkan karena asupan jumlah makanan yang kurang dari kebutuhan tubuh. Karbohidrat merupakan salah satu unsur gizi yang berfungsi sebagai energi utama, kebutuhan karbohidrat yang dianjurkan sebesar $60 \%$ dari total kalori dengan perincian $90 \%$ dari selain gula dan $10 \%$ gula Kekurangan karbohidrat dalam konsumsi makanan dapat menyebabkan keadaan malnutrisi. Dari data responden dapat dilihat berat badan sample kurang dari standart ditunjukkan dengan tubuh yang kurus.

Dari diagram distribusi frekuensi responden berdasarkan nilai protein menunjukkan bahwa sebanyak 9 responden (30\%) mempunyai nilai gizi protein baik, sedangkan 21 reponden (70\%) mempunyai nilai gizi protein kurang. Asupan protein yang kurang dapat disebabkan karena jumlah makanan yang kurang dari kebutuhan tubuh serta kurang bervariasinya jenis makanan. Dimungkinkan jenis makanan yang dikonsumsi oleh responden tergolong rendah protein. Protein merupakan salah satu unsur zat gizi yang berfungsi untuk pertumbuhan dan pemeliharaan kulit dan kuku, mengatur keseimbangan cairan, memelihara netralitas tubuh, pembentukan antibodi dan sumber energi. Kekurangan protein menyebabkan 
banyak masalah seperti kehilangan berat badan, kelemahan, penyusutan jaringan otot dan edema. Sindrom lain termasuk luar biasa tekanan darah rendah, denyut jantung sangat rendah, anemia dan pigmentasi pada kulit. Tingkat metabolisme juga cenderung menurun. Hal ini juga diyakini menyebabkan infiltrasi lemak dan sirosis hati (Erfandi, 2009).

Dari diagram distribusi frekuensi responden berdasarkan nilai lemak menunjukkan bahwa sebagian besar responden (77\%) mempunyai nilai gizi lemak yang kurang. Kurangnya nilai gizi lemak responden disebabkan salah satunya karena kurangnya jumlah asupan makanan dalam tubuh, adanya kesukaan responden terhadap jenis makanan, serta jenis makanan sebagai sumber lemak yang dikonsumsi kurang bervariasi. Pada dasarnya lemak berfungsi sebagai sumber dan cadangan energi. Lemak disimpan di jaringan bawah kulit (Pratiwi, 2009). Jika kekurangan lemak dapat menimbulkan gangguan saraf dan penglihatan, menghambat pertumbuhan pada bayi dan anak-anak, kegagalan reproduksi serta gangguan pada kulit, ginjal dan hati (Erfandi, 2009). Asupan karbohidrat, lemak dan protein yang kurang akan berakibat tidak terpenuhinya fungsi-fungsi dari unsur-unsur gizi tersebut. Dari konsumsi makan beberapa unsur gizi di atas dapat diketahui bahwa sebagian besar pasien gastritis mempunyai pola makan yang salah.

Perilaku konsumsi makan pada diri seseorang, satu keluarga atau masayarakat dipengaruhi oleh wawasan dan cara pandang dan faktor lain yang berkaitan dengan tindakan yang tepat. Di sisi lain nutrisi sangat berguna untuk menjaga kesehatan dan mencegah penyakit. Selain karena faktor kekurangan nutrisi, akhir-akhir ini juga muncul penyakit akibat salah pola makan seperti kelebihan makan atau makan makanan yang kurang seimbang. Bahkan, kematian akibat penyakit yang timbul karena pola makan yang salah atau tidak sehat belakangan ini cenderung meningkat.
Dari diagram distribusi frekuensi responden berdasarkan pola makan pasien gastritis menunjukkan bahwa sebanyak 14 responden (47\%) memiliki pola makan kurang baik. Pola makan dipengaruhi oleh budaya, agama atau kepercayaan, status sosial ekonomi, personal preference, rasa lapar, nafsu makan, rasa kenyang dan kesehatan. Pola makan yang kurang baik pada responden salah satunya disebabkan karena statusnya yang masih mahasiswa dan relatif berusia muda. Mahasiswa biasanya sangat mementingkan penampilan sehingga beberapa dari mereka melakukan diit ketat agar tetap terlihat langsing, selain itu juga bisa disebabkan karena makan yang tidak terkontrol karena jauh dari orang tua serta sibuk dengan kegiatan kampus, jauhnya dari tempat makan atau warung juga bisa mempengaruhi pola makan.

Dari diagram distribusi frekuensi responden berdasarkan timbulnya gastritis menunjukkan bahwa sebanyak 16 responden (54\%) dalam kategori gastritis akut, sebanyak 14 responden (47\%) dalam kelompok gastritis kronis. Hal ini dapat disebabkan karena sebagian besar responden memiliki pola makan kurang baik dengan pemenuhan karohidrat, protein maupun lemak yang kurang. Sebagian besar responden (54\%) menderita gastritis akut, disebabkan karena sebagian besar responden (47\%) yang masih berusia dewasa muda dan berstatus sebagai mahasiswa, dengan kesibukan kuliah serta keterbatasan waktu maupun jauhnya dari tempat makan, mereka sering meninggalkan jadwal makan sehingga pola makan mereka menjadi kurang baik dan timbul keluhan penyakit gastritis. Gastritis adalah peradangan lokal atau menyebar pada mukosa lambung yang berkembang bila mekanisme mukosa dipenuhi dengan bakteri atau bahan iritan lain (Setyono, 2001). Gastritis bisa disebabkan karena beberapa faktor (wartawarga, 2010) yaitu jadwal makan yang tidak teratur membuat lambung sulit beradaptasi dan dapat 
mengkibatkan kelebihan asam lambung dan akan mengiritasi dinding mukosa lambung, makanan yang teksturnya keras dan dimakan dalam keadaan panas misalnya bakso, mengkonsumsi minuman yang mengandung kafein seperti kopi dan teh, makanan pedas dan asam, dan makanan yang mengandung gas seperti ubi, buncis, kol dll.

Dari tabel hubungan pola makan dengan timbulnya gastritis menunjukkan bahwa sebagian besar responden (47\%) memiliki pola makan kurang baik, mengakibatkan 5 responden $(16,7 \%)$ menderita gastritis akut dan 9 responden (30\%) menderita gastritis kronis. Pola makan yang tidak baik dilihat dari segi jumlah, jenis dan fungsi dalam jangka waktu lama menyebabkan tidak terpenuhinya kebutuhan tubuh akan unsur-unsur gizi (termasuk di dalamnya karbohidrat, protein, lemak). Frekuensi makan yang tidak teratur dalam jangka waktu yang lama juga bisa menimbulkan gastritis.

Dari hasil analisis disimpulkan bahwa ada hubungan pola makan dengan timbulnya gastritis di UMM Medical Center Malang, dengan nilai $p$ value 0,009 .

Kesehatan seseorang salah satunya dipengaruhi oleh pola makan yang kurang baik (tidak teratur) menyebabkan lambung menjadi sensitif, sehingga asam lambung meningkat. Produksi $\mathrm{HCl}$ (asam lambung) yang berlebihan dapat menyebabkan terjadinya gesekan pada dinding lambung dan usus halus, sehingga timbul rasa nyeri yang disebut tukak lambung. Gesekan akan lebih parah kalau lambung dalam keadaan kosong akibat makan tidak teratur yang pada akhirnya akan mengakibatkan perdarahan pada lambung (Rafani, 2009).

Gastritis (inflamasi mukosa lambung) pada umumnya terjadi karena diet yang salah. Yaitu dengan mengonsumsi jumlah makanan yang kurang dari kebutuhan tubuh, jenis makanan yang kurang bervariasi dan tidak sehat, serta frekuensi makan yang tidak teratur dapat mempermudah terjadinya gastritis.
Kebiasaan makan makanan yang terlalu pedas, terlalu dingin atau panas, terlalu cepat, juga mendukung timbulnya gastritis. Jika keadaan itu dibiarkan akan memperparah penderita karena dapat menyebabkan perforasi atau gangren (Smeltzer, 2000).

Gastritis bukanlah suatu penyakit tunggal, namun beberapa kondisi-kondisi yang berbeda yang semuanya mempunyai peradangan lapisan lambung. Kadang, gastritis dapat menyebabkan pendarahan pada lambung, tapi hal ini jarang menjadi parah kecuali bila pada saat yang sama juga terjadi borok pada lambung. Pendarahan pada lambung dapat menyebabkan muntah darah atau terdapat darah pada feces dan memerlukan perawatan segera (Rafani, 2009).

\section{KESIMPULAN DAN SARAN}

Berdasarkan pembahasan bahwa di UMM Medical Center Malang sebagian besar responden dalam kategori pola makan kurang baik. Sebagian besar responden menderita gastritis akut dan sebagian kecil dalam kelompok gastritis kronis. Pola makan yang kurang baik menyebabkan sebagian kecil responden menderita gastritis akut dan sebagian besar responden menderita gastritis kronis. Dapat disimpulkan bahwa secara statistik terdapat hubungan antara pola makan dengan timbulnya gastritis.

Saran yang dapat diberikan yaitu perlu adanya penelitian lebih lanjut dengan sample yang lebih besar. Direkomendasikan pada pasien dan masyarakat untuk mengkonsumsi makanan yang bergizi dengan jumlah makanan yang cukup, jenis makanan yang bervariasi, frekuensi makan dengan porsi sedikit tapi sering sesuai dengan kebutuhan tubuh.

\section{DAFTAR PUSTAKA}

Aziz, A. 2007. Metode Penelitian Keperawatan dan Teknik Analisis Data. Jakarta: Salemba Medika. 
Auliana, R. 2001. Gizi dan Pengolahan Pangan. Yogyakarta: Adicita.

Baughman, D.C. 2000. Keperawatan Medikal Bedah: Buku Saku untuk Brunner dan Suddarth. Jakarta: EGC.

Dewa, I., dkk. 2002. Penilaian Status Gizi. Jakarta: EGC.

Djaeni, A. 2000. Ilmu Gizi. Jakarta Timur: Dian Rakyat.

Erfandi. 2009. Protein, Lipid dan Vitamin. Jakarta: EGC.

Farida, Y., dkk. 2004. Pengantar Pangan dan Gizi. Jakarta: Penebar Swadaya.

Inayah, I. 2004. Asuhan Keperawatan pada Klien dengan Gangguan Sistem Pencernaan. Jakarta: Salemba Medika.

Lies, A. 2004. Kesehatan dan Gizi. Jakarta: PT. Asdi Mahasatya.

Nursalam. 2008. Konsep dan Penerapan Metodologi Penelitian Ilmu keperawatan. Jakarta: Salemba Medika.

Rafani. 2009. Askep Anak dengan Gastritis. www.rafani.co.id. Diakses tanggal 2 Januari 2009 jam 18.15 WIB.

Riyanto, H. 2008. Gastritis. www.wordpress.co.id. Diakses tanggal 2 januari 2009 jam 18.25 WIB.

Setiadi. 2007. Konsep dan Penulisan Riset Keperawatan. Yogyakarta: Graha Ilmu.

Setyono, J. 2001. Keperawatan Medikal Bedah. Jakarta: EGC.

Smeltzer. 2002. Keperawatan Medikal bedah. Jakarta: EGC.

Suhardjo.1990. Penilaian Keadaan Gizi Masyarakat. Bogor: IPB.

Suharsimi, A. 1998. Prosedur Penelitian Suatu Pendekatan Praktek. Jakarta: Rineka Cipta.

Sylvia, A.P., Lorraine. 1994. Patofisiologi Proses-Proses Penyakit. Jakarta: EGC. 